\title{
Measures of store loyalty in French food retailing
}

\author{
Fabian BERGÈS*, Valérie OROZCO** \\ * Auteur correspondant : Toulouse School of Economics (GREMAQ-INRA and IDEI), \\ Manufacture des Tabacs - MA 103, 21 Allée de Brienne, F-31000 Toulouse (France) \\ e-mail :Fabian.Berges@toulouse.inra.fr \\ ** Toulouse School of Economics (GREMAQ-INRA)
}

\begin{abstract}
Summary - Store loyalty is an important issue for retailers since it defines one way in wbich consumers are attached to stores. However, store loyalty is not unidimensional and there are different ways of measuring it. After surveying the marketing literature on bow to assess 'store loyalty', we compute different store loyalty indexes with French bomescan database on consumer purchases ( 9000 bouseholds) coupled with a store database that allows us to control for supply parameters, including store location and accessibility. We find that the store loyalty index, computed on more than 250 goods, differs greatly across chain stores. Moreover, when households increase their expenditures in a store, it does not necessarily mean that the store benefits from more loyal patronage. We also investigate the relationship between store loyalty and likelibood of buying private labels (PL). Results show that a $P L$ expenditure increase does not translate into higher store loyalty (whatever the index studied).
\end{abstract}

Keywords: store loyalty, market power, private label

\section{Mesurer la fidélité à l'enseigne dans la grande distribution alimentaire en France}

Résumé - La fidélité à l'enseigne est un sujet important pour les distributeurs, car cela permet d'appréhender l'attachement des consommateurs aux distributeurs. La mesure d'un tel critère n'est cependant pas unidimensionnelle. Après un survol rapide de la littérature marketing traitant des indices de la fidélité à l'enseigne, nous calculons plusieurs indices en utilisant des données d'achats de panel sur 9000 ménages, couplées avec des données sur les enseignes afin de contrôler l'importance d'accès aux enseignes pour chaque ménage. Nous montrons que la fidélité à l'enseigne, calculée sur la base de plus de 250 produits, differe grandement d'un groupe à l'autre. De plus, l'augmentation de la part de marché d'une enseigne pour un ménage ne signifie pas nécessairement qu'il devient fortement fidèle à cette enseigne. Nous mettons également à jour une relation non-linéaire entre la fidélité à l'enseigne et la propension du ménage à acheter des marques de distributeurs. Les résultats montrent qu'une plus forte propension à acheter des marques de distributeurs ne se traduit pas par une plus importante fidélité à l'enseigne (tous indices confondus).

Mots-clés : fidélité à l'enseigne, pouvoir de marché, marques de distributeurs

Classification JEL : D1, D3, L1, Q13

This article has benefited of a financial support from the Inra Scientific Economic Department Council (CSD) as well as helpful comments from Stéphane Caprice and Gilles Grolleau. We also want to thank the SFER 2007 (Paris), Inra-SAE2 Journées Jeunes Chercheurs 2009 (Montpellier) and Toulouse's "GT Fidélitê" participants for the improving discussions. 


\section{Introduction}

Retailing for agrofood goods in Europe is mainly dominated by large retailing firms. For France in 2006, the top four retailing groups (Carrefour, Casino, Leclerc and Intermarchê) have a cumulated market share of around $70 \%$. Such a limited number of retailing firms for households raises important questions about the nature of competition between retailers. However, each retailing group owns different store names, mainly used to differentiate the type of store (hypermarkets, supermarkets, local stores) in order to avoid frontal competition with a rival group.

Since most households have access to several retailers, competition between large retailing firms has one important goal: to attract consumers and make them spend their (food) budget in the store. Such store loyalty is a precious consumer characteristic for retailers because once the consumer is in the store, he or she is more likely to buy the majority of products within the store, even if there is a price differential on particular goods compared to rival retailers (one-stop shop argument developed in Beggs, 1994). The importance of store loyalty in a country may thus provide important information on retailers' possible strategy towards consumers and producers.

First, competition policy, through an extensive legislative corpus and jurisprudential cases, aims to protect consumer welfare by forbidding any practices resulting from market power and directed against consumer interest. In order to establish such an abuse of a dominant position, the dominant position itself must first be assessed (Motta, 2004). In the retailing industry, store loyalty is a good proxy of a retail group's market power. Retailers' market power, namely their ability to increase prices from their marginal cost, does indeed come from this store loyalty mechanism. The more consumers are store loyal, the higher the market power of the retailer, and therefore the higher prices (profits) they can expect, see Steenkamp and Dekimpe (1997).

Second, considering the vertical chain between a producer and a retailer, the more store loyalty a retailer has, the more bargaining power vis-à-vis producers (upstream) it enjoys. In other words, due to the consumers' captive demand, it may negotiate lower wholesale prices with manufacturers and thus modify vertical profit shares within the chain. Store loyalty may thus also be a good proxy for assessing retailers' bargaining power, as shown in Bergès-Sennou (2006).

Last, private labels (PL) strategies initiated by retailers in the last three decades may impact store loyalty. Private labels, contrary to branded products, can only be purchased in the specific retail chain stores that own the store brand. There are economic theory foundations explaining that PL patronage increases store loyalty, such as the argument developed in Cortjens and Lal (2000) where the low prices of store brands are used by consumers as a proxy to infer the general pricing policy of the retailer. Sudhir and Talukdar (2004) give another empirically validated argument: PLs increase store differentiation through specific retailers' brands and thus create loyal demand because of store switching costs. However, Ailawadi, Pauwels and Steenkamp (2008) reveal the non linear relationship (inverse-U shape) between PL market share and store loyalty. Since PL have lower prices than branded products, a high PL market share makes the retailer's market share lower in value compared to rivals. 
The objective of this article is to give a general picture of store loyalty in France by using household homescan data on agrofood purchases enhanced by information on individual retailer access. The relationship between the development of store brands (private labels) and store loyalty is also studied.

We find that the store loyalty index (computed on more than 250 staple goods) differs greatly across French chain stores. Moreover, when households increase their expenditures in a store, it does not necessarily mean that the store benefits from a higher loyalty patronage. Besides, the likelihood of buying PL does not always translate into a higher store patronage.

Section 2 reviews the most common measures of store loyalty while section 3 describes the data and displays indexes computations. Section 4 characterizes the relationship between store brands and store loyalty. Section 5 concludes.

\section{Store loyalty definition}

In order to tackle loyalty issues, we will set out the most relevant measures used in the traditional literature and confront them with the information they provide regarding consumer behavior. Even though loyalty does not seem to be a clear-cut concept and therefore cannot be encompassed in a single statistical index, there are some common ways to approach it so that such indexes become informative.

Store loyalty is defined by the American Marketing Association as being "the degree to which a consumer consistently patronizes the same store when shopping for particular types of products". Store loyalty therefore has two dimensions: a static one that can be understood through the budget spent and retailers' market shares, and a dynamic one that may be seen through comparisons of appropriate statistics over time. Moreover, Jacoby and Kyner (1973) developed the conceptual definition for brand loyalty and identified the necessary and collectively sufficient conditions to qualify a consumer as brand loyal. The most important one is the consumer's decision bias observed towards particular brands and repeated over time. However, this theoretical condition made any measurement very complicated to establish. Mellens, Dekimpe and Steenkamp (1996) discuss several other conceptual conditions and conclude that each one involves a particular statistical index. Thus, brand loyalty cannot be aggregated in a unidimensional statistic reconciling behavioral measures (purchasing component) and attitudinal measures (cognitive element). However, Bustos-Reyes and Benito (2008) show that the different loyalty indicators based on market shares in value are highly correlated and nuances in computational formulas do not add much in terms of comprehension.

From an economic point of view, we focus on the purchasing component (which is the ex-post observable result from the cognitive component) and thus only on loyalty measures based on individual-level data. Most of the marketing literature on loyalty is about brand loyalty and defines indexes that can easily be transposed to store loyalty, as described in Popkowski and Gonul (1996). Popular measures always try to detect inertia in consumer behavior, such as a particular concentration of expenditures towards a specific brand for a given product. Store loyalty is thus not very different from brand loyalty when using a behavioral approach because the consumers' alternatives relate to stores rather than brands. 
Besides, we need to bear in mind that consumers go to retail outlets to purchase a bundle of goods, with particular brands. Therefore, brand loyalty and store loyalty are not completely disconnected since in stores, some brands attempt to retain consumer loyalty. Industrial economists like Steiner (1993) or Caprice (2004) have emphasized the important link between these two concepts and its consequence in terms of bargaining power between upstream and downstream firms. A store-loyal consumer is more inclined to change brands rather than stores if he or she does not find the brand they want ${ }^{1}$. Therefore, the more store-loyal consumers are, the more power of negotiation the retailer possesses with the brand manufacturer. The consumer is indeed going to choose another brand within the same store rather than leaving the store to buy the desired brand elsewhere. Measuring store loyalty (and its evolution) is thus a way of measuring retailers' bargaining power in the vertical chain. Besides, the largescale development of private labels (up to $28 \%$ of market share on average for France in 2006) raises the question of their impact on store loyalty.

\section{Data and index computation}

The data used come from two databases:

- The first one is a homescan database (for the year 2001) provided by the TNS Worldpanel Company, which follows a panel of French consumers (9 197 households in 2001) by referencing their purchases on more than 400 goods, as well as some of their characteristics (location, income, etc.). These panel members use a home scanner to record all their food purchases from French retailers (indicating price, quantity, gencode, place of purchase, etc.) and then the data are transmitted electronically to TNS. It is a consumer demand oriented database.

- The second database is provided by LSA (Libre-Service Actualités) and it makes a census of all supermarkets or hypermarkets in France. Among other variables, it gives their exact location. The information displayed in this database will be useful to control for supply factors.

We study store loyalty for the seven biggest French supermarket and hypermarket chains 2: Auchan, Carrefour, Casino, Champion, Intermarché, Leclerc and Système U. Their names have been replaced by numbers in order to protect corporate secrecy.

\footnotetext{
${ }_{1}^{1}$ One measure for such a concept is given by Chardon and Dumartin (1998). They asked a panel of consumers (declarative data through phone interviews) what they would do in a retail store if the brand they wished to buy was absent on the shelf. The general result is that $56 \%$ of consumers answered they would change brand rather than leaving the store (20\%) or delaying the purchase $(24 \%)$.

2 The legal definition comes from Insee (French National Statistical Agency). A supermarket is defined as an outlet with a surface area of between $400 \mathrm{~m}^{2}$ and $2500 \mathrm{~m}^{2}$, and where more than $2 / 3$ of revenue comes from agrofood goods. A hypermarket is defined as an outlet with a surface area greater than $2500 \mathrm{~m}^{2}$, and where more than $1 / 3$ of revenue comes from agrofood goods. In 2001 for France, hypermarkets and supermarkets represented $66.2 \%$ of retail outlets according to Insee.
} 
The first measure used for store loyalty was the simplest and the most intuitive one: market share in value (see Cunningham, 1956, 1961), also called Share of Wallet (SOW) ${ }^{3}$. One could argue that SOW has a lot to do with the number of outlets a household may have access to. Indeed, it is quite logical to think that you spend more at a given retailer if you have more proximity outlets (belonging to the same chain) to shop at. In fact, SOW in this case would be more the result of the market structure rather than a true and deliberate household strategy. Table 1 represents the retailer average market share in value (SOW) for all households aggregated on the 254 goods with a bar-code and its correlation with the number of the outlets of such name ${ }^{4}$.

Table 1. Market share in value for hyper and supermarkets and correlation with the number of outlets, France 2001

\begin{tabular}{lccccccccc}
\hline $\begin{array}{l}\text { Market share } \\
\text { in value }(\%)\end{array}$ & $\begin{array}{c}\text { Retailer } \\
\text { SOW }\end{array}$ & $\begin{array}{c}\text { Retailer } \\
\# 2\end{array}$ & $\begin{array}{c}\text { Retailer } \\
\# 3\end{array}$ & $\begin{array}{c}\text { Retailer } \\
\# 4\end{array}$ & $\begin{array}{c}\text { Retailer } \\
\# 5\end{array}$ & $\begin{array}{c}\text { Retailer } \\
\# 6\end{array}$ & $\begin{array}{c}\text { Retailer } \\
\# 7\end{array}$ & Others \\
\hline Mean & $17 \%$ & $13 \%$ & $13 \%$ & $9 \%$ & $7 \%$ & $7 \%$ & $4 \%$ & $32 \%$ \\
Standard-Deviation & $(0.29)$ & $(0.25)$ & $(0.24)$ & $(0.21)$ & $(0.20)$ & $(0.19)$ & $(0.13)$ & $(0.32)$ \\
Correlation coefficient $\rho$ & $0.1269 *$ & $0.2875 *$ & $-0.0338^{*}$ & $0.3424^{*}$ & $0.1 *$ & $0.0549 *$ & $0.2238^{*}$ & $0.2057^{*}$ \\
\hline
\end{tabular}

Note : * significant with a $99 \%$ confidence level.

These figures coincide with the professional statistics on chain store market shares provided by the Department manager's review Linéaires. We can distinguish two groups of retailers in France: one above 13\% (3 retailers), strongly established, the other one below $10 \%$ ( 4 retailers) even though the outlets are nationally spread. If store loyalty is measured by the market share in value, Retailer \#1 has the most loyal base, followed by Retailer \#2 and Retailer \#3. However, a look at standard deviation imposes prudence since it appears that the market share figures actually conceal a strong heterogeneity. This could mean that spending by household is strongly concentrated in some distributors rather than widely spread across all of them. Moreover, the "composite" Others (including hard discount retailers and numerous small distributors) attracts nearly $1 / 3$ of household expenditures on food commodities. Regarding the correlation between SOW and the number of outlets, the coefficient is significant but quite low in the majority.

The SOW static index is problematic since it does not encompass household characteristics such as the proximity retailers to which the household may have access. Besides, as Elrod (1988) argues, it is in substance easier to be loyal when you have access to a limited number of outlets than when you have a wide choice of retailers to

\footnotetext{
3 Instead of using market shares computed in value, one can think of market shares computed in volume (quantities). However, the figures do not differ enough from each other to discuss any discrepancy.

${ }^{4}$ Note than we worked on 254 bar-code products for which the brand and other information are clearly available. This is not the case for others products such as fruits, vegetables, meat or fish.
} 
visit around your home. Since in the TNS Worldpanel we do have the post code (zip) of each household, thanks to the LSA database we can compute how many outlets a household could have access to within a $20 \mathrm{~km}$ radius. The distance of $20 \mathrm{~km}$ for goodwill is indeed the one most commonly considered in competition cases by the French Competition Council or the European Commission ${ }^{5}$. However we sometimes find that the household did purchase outside of its proximity outlets. This could be explained by the fact that they can shop in outlets located around their workplace, and since we do not have the information on their work location in the panel data, we could not incorporate them a priori. Statistics show that $76 \%$ of households made their purchases only in proximity outlets located $20 \mathrm{~km}$ around their home, while $24 \%$ of the panel also bought goods in outlets that were supposed to be out-of-reach for them.

Table 2 gives, for each retailer, how many households (also in \%) have access to it within the $20 \mathrm{~km}$ radius.

Table 2. Retailer accessibility by household

\begin{tabular}{lcccccccc}
\hline Retailer Accessibility & Retailer & Retailer & Retailer & Retailer & Retailer & Retailer & Retailer & Others \\
& $\# 1$ & $\# 2$ & $\# 3$ & $\# 4$ & $\# 5$ & $\# 6$ & $\# 7$ & (3) \\
\hline $\begin{array}{l}\text { Number of households } \\
\begin{array}{l}\text { Proportion in \% } \\
\text { of the panel }\end{array}\end{array}$ & 8391 & 6572 & 9105 & 5305 & 7325 & 8108 & 6306 & 9195 \\
\hline
\end{tabular}

Retailer \#4 and Retailer \#7 are less accessible than the other ones. This could have an impact on store loyalty. Note that the Others composite is accessible to everyone. This is an important point since it means that it is relevant to interpret it as an outside outlet for households, wherever they live, out of the seven classic established stores.

In order to encompass the supply dimension in the loyalty analysis, we compute an indicator provided by Elrod (1988) named SPOP: Scale Probability Of Purchase. It is defined, for each household $(b)$ and retailer $(r)$, by:

$$
S P O P_{h, r}=J_{b} \cdot P_{h, r}-1
$$

where $J_{b}$ is the proximity number of retailers faced by household $(b)$ and $P_{h, r}$ is the probability of household $(b)$ buying at a retailer $(r)$, that is the market share of retailer $(r)$ in value for the household. Let us consider the two extreme cases. A household that never visits retailer $(r)$ is characterized by $P_{h, r}=0$. Its SPOP will therefore be equal to -1 (disloyal). At the other extreme, a household shopping only at retailer $(r)$ will display $P_{h, r}=1$. Its SPOP will therefore be $J_{b}-1$ (loyal). Last, a household spending equally its budget across retailers will have

$$
\left.P_{h, r}=\frac{1}{J_{b}} \text { resulting in } S P O P_{h, r}=0 \text { (average }\right)
$$

\footnotetext{
5 The French Competition Council, in its opinion 00-A-06 regarding the Carrefour/Promodès merger, states that the "goodwill zone" could be defined by a circular area within $20 \mathrm{~km}$ or 20 minutes from the considered outlet (considering only hypermarkets or supermarkets, therefore de facto excluding convenience stores).
} 
The SPOP displays the good property that the more proximity retailers the household may have access to, the harder it is to be called loyal since the maximal limit $\left(J_{b}-1\right)$ is increasing in $J_{b}$. In other words, it becomes more and more difficult for a retailer to be chosen by consumers when the number of rivals rises. Such a fundamental property was not at all present when measuring store loyalty only with market share in value because the supply side of the retail market was absent. In other words, a household may devote zero Euros of its budget to retailer $(r)$ for two reasons: either it does not have access to retailer $(r)$, or it does not want to shop at retailer $(r)$. It is fundamentally different since the second reason relies on the behavior of the household, whereas the first one has more to do with the market structure, independently of the household behavior. The SPOP dissociates these two causes (either with a missing value or with a SPOP $=-1$ ), whereas the market share in value does not (it assigns 0 in both cases) ${ }^{6}$.

Table 3 gives, for the seven retailers, the average SPOP score across households. Note that missing values, indicating that the household does not have access to the chain store considered, have not been included in the computation. If the household did buy outside the proximity retailers, a SPOP index can however be computed since $J_{b}$ can be adapted to take this situation into account.

Table 3. SPOP scores for the seven retailers

\begin{tabular}{lccccccccr}
\hline SPOP Score & $\begin{array}{c}\text { Retailer } \\
\# 1\end{array}$ & $\begin{array}{c}\text { Retailer } \\
\# 2\end{array}$ & $\begin{array}{c}\text { Retailer } \\
\# 3\end{array}$ & $\begin{array}{c}\text { Retailer } \\
\# 4\end{array}$ & $\begin{array}{c}\text { Retailer } \\
\# 5\end{array}$ & $\begin{array}{c}\text { Retailer } \\
\# 6\end{array}$ & $\begin{array}{c}\text { Retailer } \\
\# 7\end{array}$ & Others \\
\hline $\begin{array}{l}\text { Number of households } \\
\text { having access to }\end{array}$ & $\mathrm{N}=8391$ & $\mathrm{~N}=6572$ & $\mathrm{~N}=9105$ & $\mathrm{~N}=5305$ & $\mathrm{~N}=7325$ & $\mathrm{~N}=8108$ & $\mathrm{~N}=6306$ & $\mathrm{~N}=9195$ \\
the retailer considered & & & & & & & & & \\
Average & 0.18 & 0.26 & -0.22 & 0.05 & -0.50 & -0.50 & -0.66 & 1.13 \\
Standard Deviation & $(1.90)$ & $(2.04)$ & $(1.50)$ & $(1.87)$ & $(1.37)$ & $(1.31)$ & $(1.04)$ & $(2.23)$ \\
Median & -0.90 & -0.83 & -1.00 & -0.91 & -1.00 & -1.00 & -1.00 & 0.33 \\
\hline
\end{tabular}

The first comment is that, with the exception of the artificially high SPOP of Others which is due to its composite characteristic displaying a SOW slightly lower than one third, only Retailer \#1 and Retailer \#2 can display a strictly positive SPOP, whereas in Table 1, Retailer \#3 was also part of the winning trio. Refining the definition of loyalty has changed the ranking. Retailer \#4 now breaks away from the last 4 retailers, whereas Retailer \#7 seems to be on the same level of loyalty as Retailer \#5 and Retailer \#6. The second comment is that, relating these results to Table 2 on accessibility, Retailer \#4 displays a better loyalty score despite its poor average accessibility (compared to Retailer \#3 that is more accessible). Additionally, Retailer \#7 exhibits a store loyalty index close to that of Retailer \#5 and Retailer \#6 whereas fewer households may have access to it. In conclusion, we can say that on average, consumers are more loyal to Retailer \#1 and Retailer \#2 whereas Retailer \#5 and Retailer \#6 do show a very low performance given their high accessibility rate. Aggregate data conceal a strong heterogeneity as indicated by large standard deviations.

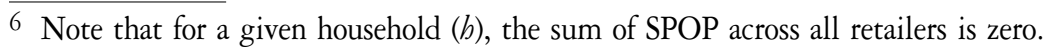


Dubois and Laurent (1999) already pointed out this problem: average scores may hide opposite individual moves. One possible remedy is to look at the proportion of 'highly loyal' consumers for each retailer rather than at the average SPOP.

When can we say that a consumer is highly loyal to a retailer? One answer could be to compare his behavior with the average behavior. According to our data, the average number of accessible retailers is $\bar{J}_{b}=6$, whereas a household visits 3 different retailers a year on average. The reference probability of purchase for each retailer is thus $1 / 3$ (splitting the budget equally). The average SPOP for an average household is therefore 1. If a household has a SPOP higher than 1, it will be considered highly loyal, otherwise not. Note that as the number of proximity retailers rises, it becomes more and more difficult for a household to be declared highly loyal (SPOP property).

Table 4 gives, for each retailer, the proportion of highly loyal consumers (having a SPOP higher than 1).

Table 4. Proportion of highly loyal consumers by retailer

\begin{tabular}{lcccccccc}
\hline High Store Loyalty & $\begin{array}{c}\text { Retailer } \\
\# 1\end{array}$ & $\begin{array}{c}\text { Retailer } \\
\# 2\end{array}$ & $\begin{array}{c}\text { Retailer } \\
\# 3\end{array}$ & $\begin{array}{c}\text { Retailer } \\
\# 4\end{array}$ & $\begin{array}{c}\text { Retailer } \\
\# 5\end{array}$ & $\begin{array}{c}\text { Retailer } \\
\# 6\end{array}$ & $\begin{array}{c}\text { Retailer } \\
\# 7\end{array}$ & Others \\
\hline $\begin{array}{l}\text { Total number } \\
\text { of households }\end{array}$ & 8391 & 6572 & 9105 & 5305 & 7325 & 8108 & 6306 & 9195 \\
$\begin{array}{l}\text { High-Loyalty } \\
\text { Proportion }\end{array}$ & $22.55 \%$ & $22.29 \%$ & $14.79 \%$ & $18.32 \%$ & $9.45 \%$ & $9.57 \%$ & $5.79 \%$ & $40.32 \%$ \\
\hline
\end{tabular}

One interesting question is to know whether the SPOP varies across socioeconomic groups ${ }^{7}$. We computed the SPOP index and the proportion of highly loyal consumers separately by segmenting rural / urban areas, for different income class levels as well as for retailer concentration (using the Herfindahl-Hirschman Index $\mathrm{HHI})$. Tables 5 and 6 summarize the results.

Whereas the income segmentation shows no difference in mean across categories (not displayed), rural/urban categorization clearly indicates that SPOP in rural areas is on $6 / 8$ cases greater than or equal to the SPOP in urban areas. This seems to be due to the fact that, on average, the number of accessible retailers is lower in rural areas than in urban areas, resulting mechanically in a higher SPOP and thus in a higher store loyalty. This effect is of the same magnitude regarding retailer concentration since in 6/8 cases, SPOP is greater or equal in low-concentrated areas compared to areas where the HHI is higher than the median. This can also be explained by a slightly lower number of accessible retailers in zones where, by definition, concentration is low.

In order to tackle the issue of dynamics in store loyalty, we compare the loyalty rate evolution across years. We have the consumption data from 1998 to 2001. Restricting our panel to households present from 1998 to 2001, we give the evolution of their average SPOP and the proportion of highly loyal consumers in Table $6^{8}$.

\footnotetext{
7 We thank one referee for this idea.

${ }^{8}$ Comparing Tables (3-4) and Table 7 shows that restricting the panel only to households present from 1998 to 2001 in the master database does not change results on SPOP or on store-loyal consumers.
} 
Table 5. SPOP index for rural/urban consumers

\begin{tabular}{crrrcc}
\hline \multirow{2}{*}{ Retailer } & \multicolumn{2}{c}{ Urban } & \multicolumn{2}{c}{ Rural } & Equality test \\
\cline { 2 - 6 } & \multicolumn{1}{c}{$\bar{J}_{b}=6.849(1.238)$} & \multicolumn{1}{c}{$\bar{J}_{b}=5.760(1.286)$} & Rejected $(>)$ \\
\cline { 2 - 6 } & \multicolumn{1}{c}{$\boldsymbol{N}$} & \multicolumn{1}{c}{$\boldsymbol{S P O P}$} & \multicolumn{1}{c}{$\boldsymbol{N}$} & \multicolumn{1}{c}{ SPOP } & $\boldsymbol{H}_{0}: \overline{\boldsymbol{S P O P}}_{\text {urban }}=\overline{\mathbf{S P O P}}_{\text {rural }}$ \\
\hline$\# 1$ & 6281 & $0.12(1.92)$ & 2110 & $0.35(1.86)$ & rejected $(<)$ \\
$\# 2$ & 5248 & $0.35(2.14)$ & 1324 & $-0.09(1.59)$ & rejected $(>)$ \\
$\# 3$ & 6706 & $-0.28(1.49)$ & 2399 & $-0.06(1.52)$ & rejected $(<)$ \\
$\# 4$ & 4501 & $0.06(1.9)$ & 804 & $-0.01(1.69)$ & failed to reject \\
$\# 5$ & 5525 & $-0.63(1.22)$ & 1800 & $-0.11(1.69)$ & rejected $(<)$ \\
$\# 6$ & 6108 & $-0.49(1.36)$ & 2000 & $-0.52(1.13)$ & failed to reject \\
$\# 7$ & 5007 & $-0.67(1.04)$ & 1299 & $-0.61(1.00)$ & rejected $(<)$ \\
Others & 6732 & $1.31(2.37)$ & 2463 & $0.64(1.72)$ & rejected $(>)$
\end{tabular}

Notes: The equality test performs a t-test on the equality of means between SPOP of rural and urban area. The results of the tests are given at a $95 \%$ confidence level.

Table 6. SPOP index by retailing concentration

\begin{tabular}{cccccc}
\hline \multirow{2}{*}{ Retailer } & \multicolumn{2}{c}{ Low HHI } & \multicolumn{2}{c}{ High HHI } & Equality test \\
\cline { 2 - 6 } & \multicolumn{1}{c}{$\bar{J}_{b}=6.580(1.301)$} & \multicolumn{1}{c}{$\bar{J}_{b}=6.538(1.374)$} & failed to reject \\
\cline { 2 - 6 } & \multicolumn{1}{c}{$\boldsymbol{N}$} & \multicolumn{1}{c}{ SPOP } & \multicolumn{1}{c}{$\boldsymbol{N}$} & \multicolumn{1}{c}{ SPOP } & $H_{0}: \overline{\text { SPOP }}_{\text {Low HHI }}=\overline{\text { SPOP }}_{\text {High HHI }}$ \\
\hline$\# 1$ & 3779 & $0.14(1.86)$ & 4612 & $0.20(1.94)$ & failed to reject \\
$\# 2$ & 2996 & $0.40(2.11)$ & 3576 & $0.14(1.98)$ & rejected $(>)$ \\
$\# 3$ & 4144 & $-0.06(1.61)$ & 4961 & $-0.35(1.39)$ & rejected $(>)$ \\
$\# 4$ & 2236 & $0.11(1.94)$ & 3069 & $0.00(1.82)$ & rejected $(>)$ \\
$\# 5$ & 3297 & $-0.59(1.24)$ & 4028 & $-0.42(1.46)$ & rejected $(<)$ \\
$\# 6$ & 3841 & $-0.48(1.31)$ & 4267 & $-0.51(1.31)$ & failed to reject \\
$\# 7$ & 3160 & $-0.55(1.19)$ & 3146 & $-0.77(0.84)$ & rejected $(>)$ \\
Others & 4202 & $0.90(2.04)$ & 4993 & $1.32(2.37)$ & rejected $(<)$ \\
\hline
\end{tabular}

Notes: The equality test performs a t-test on the equality of means between SPOP of high and low concentration area. The results of the tests are given at a $95 \%$ confidence level.

Retailer \#1 and Retailer \#2 really display a net increase in their average consumers' store loyalty (SPOP score), followed in this performance by Retailer \#6 and Retailer \#5. The other chains either maintain their score (like Retailer \#7) or see their loyalty rate diminish (Retailer \#3 and Retailer \#4) along years. The conversion of the SPOP evolution in terms of customer loyalty (or more precisely, high loyalty) is not straightforward. For instance, while Retailer \#2 and Retailer \#6 seem to show the highest increase in their SPOP scores as well as in their highly loyal consumers' rate, Retailer \#1 no longer performs so well in terms of high-loyalty capitalization. This last chain captures more spending from households on average, but does not succeed in getting over the necessary threshold where households are considered to be highly loyal. In other words, Table 7 shows that households may concentrate their spending 
Table 7. Evolution of store loyalty for 1998-2001

\begin{tabular}{|c|c|c|c|c|c|c|c|c|c|}
\hline \multirow{2}{*}{$\begin{array}{l}\text { Retailer / } \\
\text { Year }\end{array}$} & \multicolumn{4}{|c|}{ Average SPOP score } & \multicolumn{4}{|c|}{$\begin{array}{l}\text { Proportion of highly loyal } \\
\text { consumers }(\%)\end{array}$} & \multirow{2}{*}{$\begin{array}{l}\text { Evolution } \\
1998-2001 \\
\end{array}$} \\
\hline & 1998 & 1999 & & & 1998 & 1999 & 2000 & 2001 & \\
\hline & & & & 0.17 & 21.12 & 21.15 & 21.93 & 22.52 & +1.1 pts \\
\hline & 0.00 & ?ח0 & & & 16.8 & & 94 & 21.61 & \\
\hline & & -0 . & & -0 . & 16.23 & & 15.76 & & \\
\hline Retailer \#4 & & & & & & & & 17.90 & \\
\hline Retailer \#5 & -0.58 & 053 & 051 & 047 & & & 9.08 & 9.99 & $+2.1 \mathrm{pts}$ \\
\hline & -0.75 & -0.73 & -0.67 & -0.46 & & & & 10.41 & $+6.1 \mathrm{pts}$ \\
\hline Retailer \#7 & -0.65 & -0.66 & -0.67 & -0.67 & & 5.66 & 5.58 & 5.63 & +0.3 pts \\
\hline Others & 1.59 & 1.54 & 1.40 & 1.07 & 49.12 & 48.12 & 46.82 & 38.87 & -10.3 pts \\
\hline
\end{tabular}

on a particular retailer (higher SPOP), but not sufficiently on average to increase the proportion of highly-loyal consumers. This may have important managerial implications since retailers devote a lot of resources (promotions, rebates, loyalty programs) to increasing consumer store loyalty and the literature seems to state that the impact of such a strategy is mitigated (see Meyer-Waarden and Benavent, 2008, or Demoulin and Zidda, 2008). Our conclusion gives new insight in the sense that a retailer's policy to increase the average household budget spent at a retailer does not necessarily increase its proportion of highly loyal consumers because the initial average SPOP of the retailer may be far from the relevant threshold to reach.

Another interesting way to capture whether consumers concentrate their food expenditures on a particular retailer, in an one-dimensional way, is to compute the classic Gini index. For our purpose, frequencies are given by market shares for each retailer. For every household, there is therefore a single number ranging from 0 (no concentration) to 0.875 (exclusive buying) characterizing the concentration of its budget on a particular retailer (even if the favorite retailer differs across consumers) ${ }^{9}$. The Gini absolute index $\left(G_{a}^{b}\right)$ is computed with the following formula for each household $b$ :

$$
G_{a}^{b}=1-\sum_{n=1}^{N} \frac{1}{N}\left[m_{n-1}^{b}+m_{n}^{b}\right]
$$

where $m_{n}^{b}$ represents the cumulative market share $(m)$ of the retailers associated with rank $(n)$ and $\mathrm{N}=8$, the total number of retailers.

Figure 1 displays the Gini index distribution for the 9197 households.

At first glance, we confirm that households concentrate their expenditures highly on a low number of selected retailers. But this image is partially informative since the

9 The fact that the maximum absolute Gini index is 0.875 comes from the limited number of retailers, equal to 8 . The basis used for computing the index is therefore divided into 8 equal sections. The section is then used to report market share devoted to the retailer considered and the Gini index is computed with the trapezoidal area method. A consumer spending all his or her budget at one retailer therefore has an index equal to $1-1 / 8=0.875$. 
Figure 1. Standard Gini distribution for expenditure concentration (kernel density added)

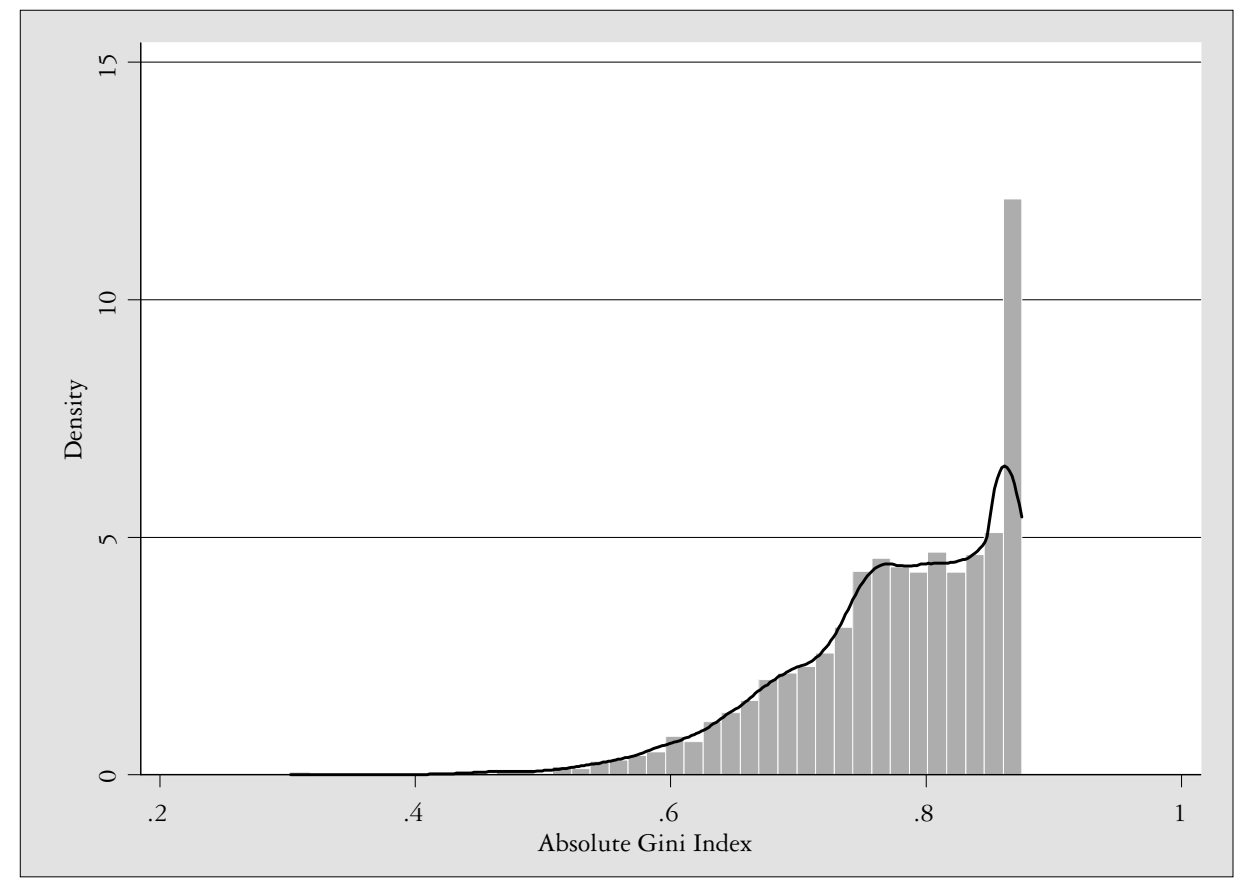

Mean: 0.78; Std Dev: 0.08; Median: 0.79; Min.: 0.3; Max.: 0.875

retailers have been attributed an implicit equal market share a priori. The base used for the Gini index $(\mathrm{N})$ is indeed defined here by a $1 / 8=12.5 \%$ not reflecting the true importance (market share) of each retailer. If the advantage of the Gini index is to summarize quickly (and graphically) a concentration pattern of household expenditures, it however fails to take into account the market structure of retailers' forces in presence. Indeed, some retailers may be less present in geographical areas than others resulting in a difference of consumer behavior due to the retailers' network ${ }^{10}$.

To correct this bias and incorporate the fact that it is easier for consumers to devote more money to bigger retailers (because they offer a wider product range or greater outlet coverage), we use the relative Gini index $\left(G_{r}^{b}\right)^{11}$. Its formula for any household $\mathrm{h}$ is the following:

$$
G_{r}^{b}=1-\sum_{n=1}^{J_{b}} K_{n}^{b}\left[m_{n-1}^{h}+m_{n}^{h}\right]
$$

\footnotetext{
${ }^{10}$ Most of the retailers are present in all geographical regions in France, except Retailer \#4 as indicated in Table 2.

${ }^{11}$ It is important to note that retailers do not own the same format networks, indeed they differ in their outlet characteristics (size). To be more precise, retailers \#1, \#2 and \#4 very predominantly own hypermarkets whereas retailers \#3, \#5 and \#6 exclusively own supermarkets. Only retailer \#7 has a mix of outlets. The composite distributor 'Others' is a mix of different retailers exclusively owning supermarket outlets. Except for retailer \#7, there is therefore no ambiguity about the characteristics of outlets within a retailer chain.
} 
Figure 2. Relative Gini distribution for expenditure concentration (kernel density added)

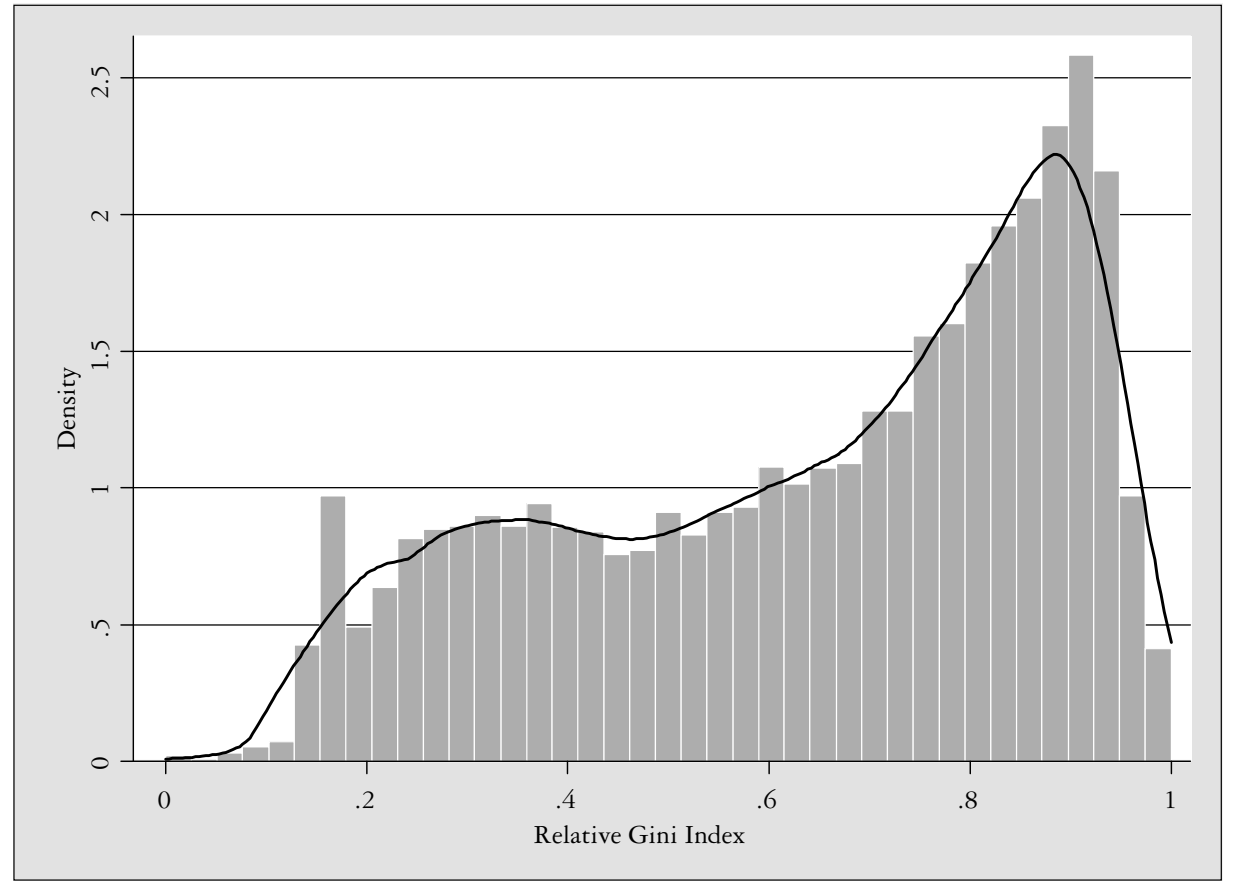

Mean: 0.64; Std Dev: 0.24; Median: 0.70; Min.: 0; Max.: 1

where $K_{n}^{b}$ is the ratio between the number of proximity outlets of the chain store considered of rank $(n)$ and the total number of outlets of all retailers ${ }^{12}$.

Contrary to the absolute Gini index, in the relative Gini framework, the parameter $K$ used for each household is proportional to the number of accessible outlets for a given chain store. It therefore removes some artificial bias towards smaller retailers. Figure 2 depicts the relative Gini index summary and distribution for the 9197 households.

The correction made to take into account, for each household, different retailers' forces on the market results in a less concentrated Gini distribution. Even if expenditures are quite concentrated on a restricted number of distributors (high mean and median), some consumers seem to bring competition into play across retailers (although not so much) by spreading their food expenditures across stores (index under $0.5)$. Whereas the standard Gini index began at more than 0.5, the relative Gini equalizes the distribution but still shows a high concentration on one retailer.

12 We conserved the same households' retailers choice set as used for the SPOP computation, using a radius of $20 \mathrm{~km}$ around their home. 


\section{Store loyalty and private labels}

Over the last three decades, retailers have developed their own products, called private labels or store brands. These products, owned and managed by the retailer, have major implications in the negotiation process between distributors and branded goods manufacturers (tariff concessions, supply strategies as in Mills, 1995), but they also modify competition between retailers (see Bergès-Sennou et al., 2004). Unlike branded products for which consumers can buy the same good in many different chain outlets (CocaCola, Danone, Nestlé, etc.), private labels are only available at the retailers that own the brand name. This deeply modifies the consumer's decision since intrabrand competition on private labels does not exist strictly speaking. Private labels may therefore affect store loyalty in two ways. The most evident one is that if you are loyal to a private label, your store loyalty mechanically increases since a given private label is only available in a given retailer's store. Therefore, you devote more budget to this specific store at the detriment of rival retailers. Causality may however be reversed since more store loyalty may translate into more PL purchases. The second effect is that consumers that buy private labels in a store may also conveniently purchase other goods (whatever their brands) in the same store rather than at rival retailers (one-stop shopping argument), increasing thereby store loyalty for the considered retailer by devoting it extra budget.

The easiest way to see whether store loyalty is conditioned by private label attitude is to compute the correlation across households between store loyalty (SPOP measure) and the household private label expenditure market shares (given a particular chain store). This will denote a behavioral bias between likelihood of purchasing private labels and store loyalty. Table 8 gives the correlation coefficients:

Table 8. Correlations between SPOP and PL expenditures

\begin{tabular}{lcccccccc}
\hline $\begin{array}{l}\text { Correlation } \\
\text { coefficient }\end{array}$ & $\begin{array}{c}\text { Retailer } \\
\# 1\end{array}$ & $\begin{array}{c}\text { Retailer } \\
\# 2\end{array}$ & $\begin{array}{c}\text { Retailer } \\
\# 3\end{array}$ & $\begin{array}{c}\text { Retailer } \\
\# 4\end{array}$ & $\begin{array}{c}\text { Retailer } \\
\# 5\end{array}$ & $\begin{array}{c}\text { Retailer } \\
\# 6\end{array}$ & $\begin{array}{c}\text { Retailer } \\
\# 7\end{array}$ & Others \\
\hline $\begin{array}{l}\text { Coefficient } \rho \\
\text { (PL by retailer and SPOP) }\end{array}$ & $0.2574 *$ & $0.1511 *$ & $0.2691 *$ & $0.2306^{*}$ & $0.3103 *$ & $0.3045 *$ & $0.2411 *$ & $0.1179 *$ \\
$\begin{array}{l}\text { Retailer's PL offer } \\
\text { (in \% of total references) }\end{array}$ & $26.92 \%$ & $22.60 \%$ & $34.37 \%$ & $18.71 \%$ & $23.23 \%$ & $27.34 \%$ & $27.5 \%$ & $\|$ \\
\hline
\end{tabular}

Note: * significant with a $99 \%$ confidence level.

Table 8 indicates first that consumers buying more PL in a given retailer are also more store loyal. There is of course the mechanical relationship coming from retailer's market share increase due to PL purchases, but the correlation coefficient is too low to conclude that these consumers also buy more of other products (that are not PLs) in the same store. Besides, the PL offer from the retailer in terms of store brand references (PL references/total product references) does not explain the magnitude of the correlation coefficient. PL purchasing likelihood and store loyalty are not therefore clearly related. However, as pointed out by Ailawadi, Pauwels \& Steenkamp (2008), the relationship between PL and store loyalty may not be linear since they exhibit an inverse-U shape ${ }^{13}$.

$\overline{13}$ This reference was given by one referee in order to push investigations about PLs and loyalty further. 
Table 9. Relationship between PL share and Store loyalty

\begin{tabular}{|c|c|c|c|c|c|c|c|}
\hline \multirow{2}{*}{\multicolumn{2}{|c|}{ Average Values }} & \multicolumn{6}{|c|}{ PL Share at the retailer: } \\
\hline & & $<5 \%$ & $5 \%-10 \%$ & $10 \%-20 \%$ & $20 \%-40 \%$ & $40 \%-60 \%$ & $>60 \%$ \\
\hline \multirow{4}{*}{ Retailer \#1 } & $\mathrm{N}$ & 6188 & 1187 & 1248 & 464 & 62 & 48 \\
\hline & Share of Wallet & 0.07 & 0.42 & 0.39 & 0.3 & 0.15 & 0.06 \\
\hline & SPOP & -0.51 & 1.68 & 1.44 & 0.85 & -0.1 & -0.64 \\
\hline & Highly Loyal (\%) & 9.09 & 53.16 & 48.48 & 33.62 & 14.52 & 4.17 \\
\hline \multirow{4}{*}{ Retailer \#2 } & $\mathrm{N}$ & 6353 & 951 & 1121 & 590 & 101 & 81 \\
\hline & Share of Wallet & 0.05 & 0.36 & 0.33 & 0.25 & 0.12 & 0.06 \\
\hline & SPOP & -0.44 & 1.56 & 1.32 & 0.74 & -0.16 & -0.59 \\
\hline & Highly Loyal (\%) & 9.74 & 45.85 & 41.03 & 31.69 & 14.85 & 4.94 \\
\hline \multirow{4}{*}{ Retailer \#3 } & $\mathrm{N}$ & 6371 & 988 & 1101 & 575 & 99 & 63 \\
\hline & Share of Wallet & 0.05 & 0.32 & 0.32 & 0.25 & 0.14 & 0.11 \\
\hline & SPOP & -0.69 & 1.03 & 0.94 & 0.47 & -0.13 & -0.33 \\
\hline & Highly Loyal (\%) & 5.64 & 39.78 & 37.69 & 28.17 & 16.16 & 11.11 \\
\hline \multirow{4}{*}{ Retailer \#4 } & $\mathrm{N}$ & 7139 & 673 & 841 & 430 & 80 & 34 \\
\hline & Share of Wallet & 0.02 & 0.33 & 0.32 & 0.23 & 0.15 & 0.07 \\
\hline & SPOP & -0.61 & 1.36 & 1.25 & 0.63 & 0.08 & -0.57 \\
\hline & Highly Loyal (\%) & 6.31 & 43.68 & 40.67 & 26.98 & 17.5 & 2.94 \\
\hline \multirow{4}{*}{ Retailer \#5 } & $\mathrm{N}$ & 7891 & 480 & 493 & 253 & 45 & 35 \\
\hline & Share of Wallet & 0.02 & 0.42 & 0.4 & 0.27 & 0.08 & 0.04 \\
\hline & SPOP & -0.86 & 1.59 & 1.36 & 0.54 & -0.53 & -0.71 \\
\hline & Highly Loyal (\%) & 2.34 & 50.63 & 47.46 & 27.27 & 8.89 & 2.86 \\
\hline \multirow{4}{*}{ Retailer \#6 } & $\mathrm{N}$ & 7513 & 552 & 663 & 350 & 71 & 48 \\
\hline & Share of Wallet & 0.02 & 0.33 & 0.31 & 0.23 & 0.16 & 0.07 \\
\hline & SPOP & -0.84 & 1.09 & 0.99 & 0.41 & 0.02 & -0.58 \\
\hline & Highly Loyal (\%) & 2.9 & 40.76 & 39.37 & 26 & 14.08 & 6.25 \\
\hline \multirow{4}{*}{ Retailer \#7 } & $\mathrm{N}$ & 8044 & 372 & 409 & 272 & 51 & 49 \\
\hline & Share of Wallet & 0.01 & 0.27 & 0.23 & 0.15 & 0.08 & 0.04 \\
\hline & SPOP & -0.89 & 0.79 & 0.58 & -0.02 & -0.5 & -0.72 \\
\hline & Highly Loyal (\%) & 1.59 & 34.95 & 26.89 & 14.71 & 1.96 & 4.08 \\
\hline \multirow{4}{*}{ Others } & $\mathrm{N}$ & 4144 & 1666 & 2023 & 1073 & 193 & 98 \\
\hline & Share of Wallet & 0.21 & 0.45 & 0.44 & 0.38 & 0.29 & 0.19 \\
\hline & SPOP & 0.4 & 1.97 & 1.85 & 1.45 & 0.79 & 0.2 \\
\hline & Highly Loyal (\%) & 23.47 & 58.16 & 57.64 & 48.28 & 32.64 & 19.39 \\
\hline
\end{tabular}

We therefore compute store loyalty indexes for each retailer by parting consumers according to their average market share devoted to private labels at the considered retailer (measure of PL purchasing likelihood). Results are given in Table 9.

For all the retailers, we find the same non-linear relationship as in Ailawadi, Pauwels \& Steenkamp (2008): an inverse U-shape between PL purchasing likelihood and store loyalty indexes. The main explanation relies on the price differential between branded products and private labels: the latter are $20 \%$ less expensive on average than the former. Therefore, considering a consumer buying quantity Q1 at retailer R1 and 
spending S2 at retailer R2 (constant), if Q1 is mainly composed of private labels, the SOW at retailer R1 will be lower than if the basket was composed of branded products, which are more expensive since SOW is computed in values. Indeed, denoting PPL and PNB respectively the PL and NB prices, it results that:

$$
S O W_{P L}^{R 1}=\frac{p_{P L} \cdot Q 1}{p_{P L} \cdot Q 1+S 2}<\frac{p_{N B} \cdot Q 1}{p_{N B} \cdot Q 1+S 2}=S O W_{N B}^{R 1} \text { because } p_{P L}<p_{N B}
$$

More PL purchasing likelihood thus translates into less store loyalty (whatever the index), ceteris paribus. This may be surprising considering retailers' strategy devoted to strongly developing their private label range and references. However, such a relationship does not preclude any causality from one variable to another.

\section{Conclusion}

This article is a first step towards capturing, from a descriptive point of view and using economic concepts, what loyalty is for consumers. We surveyed the marketing literature and tried to extract the most appropriate indicator that could be used with a homescan database. It turned out that the market share for each retailer was not sufficiently accurate since it did not take the potential offer of the retailers each household faces into account. The SPOP index used indicated that it was important to individualize the supply side of agrofood retailing by censing how many retail stores were accessible within a $20 \mathrm{~km}$ radius around the household home. We showed that increasing a market share for a retailer did not necessarily result in an increase in store loyalty because of a threshold effect (which defines households as highly loyal).

Moreover, using a classic concentration ratio (like Gini), we showed that most households concentrate their spending highly across a very limited number of stores. Store loyalty is thus very high in France and the link between store brand purchases and store loyalty exhibits an inverse- $U$ shape: an increase in PL purchasing likelihood does not translate into an increase in store loyalty, mainly because of the price differential between branded goods and store brand products.

This work should be seen as a first attempt to use marketing tools to assess store loyalty and to investigate its relation to private label development. Future research could concentrate on finding the determinants of household loyalty. Clearly, retailers may impact on store loyalty by providing services to consumers (parking places, shopping mall, numerous cash desks, attractive price offers, etc.) while the distance from household to outlet may be of prior importance.

Such issues may be of relevance to Competition Authorities since the retailing sector has always been under scrutiny for its presumed market power (see Putsis and Cotterill, 1999), mainly resulting from consumers' store loyalty (one-stop shopping). 


\section{References}

Ailawadi K., Pauwels K. and Steenkamp J.B. (2008) Private label use and store loyalty, Journal of Marketing 72(6), 19-30.

Beggs A. (1994) Mergers and Malls, Journal of Industrial Economics 42, 419-428.

Bergès-Sennou F. (2006) Store loyalty, bargaining power and the private label production issue, European Review of Agricultural Economics 33(3), 315-335.

Bergès-Sennou F., Bontems P. and Réquillart V. (2004) Economics of private label: A survey of literature, Journal of Agricultural and Food Industrial Organization 2(1), article $3,25 \mathrm{p}$.

Bustos-Reyes C., González-Benito Ó. (2008) Store and store format loyalty measures based on budget allocation, Journal of Business Research 61, 1015-1025.

Caprice S. (2004) Fidélité à la marque, fidélité à l'enseigne: une analyse des déterminants des rapports de force entre "producteurs-distributeurs", Économie Rurale 283-284, 3-15.

Chardon O., Dumartin S. (1998) Fidélité aux enseignes, fidélité aux marques : le choix des consommateurs, Insee Première 609, septembre, 4 pages.

Corstjens M., Lal R. (2000) Building store loyalty through store brands, Journal of Marketing Research 37, 281-291.

Cunningham R. (1961) Consumer loyalty to store and brand, Harvard Business Review November - December, 127-137.

Cunningham R. (1956) Brand loyalty-What, where, how much?, Harvard Business Review January-February, 116-128.

Demoulin N., Zidda P. (2008) Les cartes de fidélité fidélisent-elles la clientèle ?, Reflets et Perspectives XLVII (2),35-41.

Dubois B., Laurent G. (1999) A situation approach to brand loyalty, Advances in Consumer Research 26, 657-663.

Elrod T. (1988) A management science assessment of a behavioral measure of brand loyalty, Advances in Consumer Research 15, 481-486.

Jacoby J., Kyner D. (1973) Brand loyalty vs repeat purchasing behavior, Journal of Marketing Research X, 1-9.

Mellens M., Dekimpe M. and Steenkamp J.B. (1996) A review of brand loyalty measures in marketing, Tijdschrift voor Economie en Management XLI (4), 507-533.

Meyer-Waarden L., Benavent C. (2008) Grocery retail loyalty program effects: Selfselection or purchase behavior change?, Journal of the Academy of Marketing Science, November.

Mills D. (1995) Why retailers sell private labels?, Journal of Economics and Management Strategy 4, 509-528. 
Motta M. (2004) Competition Policy, Theory and Practice, Cambridge (MA), Cambridge University Press, 704 p.

Popkowski Leszczyc P., Gonul F. (1996) Multiple ways of measuring brand loyalty, The Canadian Journal of Economics 29(2), 494-497.

Putsis W. Jr., Cotterill R. (1999) Share, price and category expenditure-geographic market effects and private labels, Managerial and Decision Economics 20(4), 175187.

Steenkamp J.B., Dekimpe M. (1997) The increasing power of store brands: Building loyalty and market share, Long Range Planning 30(6), 917-930.

Steiner R. (1993) The inverse association between the margins of manufacturers and retailers, Review of Industrial Organization 8, 717-740.

Sudhir K., Talukdar D. (2004) Does store brand patronage improve store patronage?, Review of Industrial Organization 24, 143-160. 